\title{
Treatment of critical defects produced in calvaria of mice with mesenchymal stem cells
}

\author{
BETÂNIA S. MONTEIRO ${ }^{1 *}$, NAPOLEÃO M. ARGÔLO-NETO ${ }^{1 *}$, NANCE B. NARDI ${ }^{2}$, \\ PEDRO C. CHAGASTELLES ${ }^{2}$, PABLO H. CARVALHO ${ }^{1}$, LAILA P. BONFÁ ${ }^{1}$, \\ RICHARD R. FILGUEIRAS ${ }^{3}$, AMANDA S. REIS ${ }^{1}$ and RICARDO J. DEL CARLO ${ }^{1 *}$ \\ ${ }^{1}$ Departamento de Veterinária (DVT), Universidade Federal de Viçosa (UFV), \\ Av. P.H. Rolfs, s/n, Campus Universitário, 36570-000 Viçosa, MG, Brasil \\ ${ }^{2}$ Departamento de Imunogenética, Universidade Federal do Rio Grande do Sul (UFRGS), \\ Av. Farroupilha, 8001, Prédio 6, Sala 124, Bairro São José, 92425-900 Canoas, RS, Brasil \\ ${ }^{3}$ Hospital Veterinário Clemenceau, SAIS, 1t 14, 70610-000 Brasília, DF, Brasil
}

Manuscript received on February 7, 2011; accepted for publication on March 6, 2012

\begin{abstract}
Mesenchymal stem cells (MSC) are present in specialized niches in perivascular regions of adult tissues and are able to differentiate into various cell types, such as those committed to repairing. Bone marrow derived MSC from eight young mice C57BL/ $6 g f p^{+}$were expanded in culture for repairing critical defects in calvarial bone produced in twenty-four young isogenic adult C57BL/6 mice. The animals were subjected to a cranial defect of $6.0 \mathrm{~mm}$ diameter and divided into two equal experimental groups. Control group did not receive any treatment and the treated group received a MSC pellet containing $1.0 \times 10^{7}$ cells $/ \mathrm{mL}$ into the defects. The group treated with MSC showed increased angiogenesis and amount of new bone deposited on the defect limits than that observed in the control group. The results demonstrated that transplantation of bone marrow-derived MSC of C57BL/6 $g f p^{+}$mice to bone critical defects produced in mice calvarial contributes positively to the bone repair process. MSC presets ability to influence the correct functioning of osteoblasts, increases the amount of mobilized cells for the repairing process, speeds up growth, and increases deposition of bone matrix.
\end{abstract}

Key words: Bone therapy, Mesenchymal stem cell, Autologous graft, Mice, Calvaria.

\section{INTRODUCTION}

Mesenchymal stem cells (MSC) are somatic stem cells found in specialized niches in the perivascular regions of adult tissues (Caplan 1991, Meirelles et al. 2008), able to differentiate into tissues of mesenchymal, ectodermal and endodermal origin, such as fat, bone, cartilage, neural, among others (Pittenger et al. 1999, Caplan 2009, Breyner et al. 2010).

\footnotetext{
*These authors contributed equally to this article Correspondence to: Betânia S. Monteiro E-mail: betania.monteiro@uvv.br
}

This cellular type has been routinely isolated from various tissues, especially from bone marrow (BM), and widely expanded in cultures by successive mitoses. In cultures, it has been characterized by its fibroblastoid shape, ability to adhere to plastic substrate and differentiation capacity (Nardi and Meirelles 2006). Characteristics of plasticity, ability to expand and the possibility of being vectors for gene therapy make this cellular group target of interest in the regenerative medicine (Deans and Moseley 2000, Muraki et al. 2006). 
Some in vitro studies have illustrated the direct andindirectparticipation ofMSC inbonehomeostasis. They act as a progenitor source of osteoblasts, via cell differentiation, and regulates osteoclastogenesis, via RANKL expression (receptor activator of nuclear factor $\kappa \mathrm{B}$ ), and OPG (osteoprotegerin) (Bielby et al. 2007). In addition, the cell-cell contact determines the production of different soluble growth factors including G-CSF (granulocyte colony-stimulating factor), MG-CSF (granulocyte-macrophage colonystimulating factor), M-CSF (macrophage colonystimulating factor) and various interleukins (IL$1,6,7,8,11,12,14,15)$, which influence other young undifferentiated osteocompromised cells and granulocytic cells involved in the inflammation process (Deans and Moseley 2000, Bobis et al. 2006).

In fractures, bone repair provided by MSC occurs both, by intramembranous and endochondral ossification. The differential in these processes is that MSC, in addition to its ability of influencing the right functioning of osteoblasts, increment the quantity of mobilized cells and increase growth rate and deposition of bone matrix (Horwitz et al. 1999).

The present study investigated the usefulness of bone marrow derived MSC expanded in culture for repairing calvaria critical defects in young isogenic C57BL/6 mice. The calvaria is the fronto-parietal portion of the skull, a region with limited capacity of repair. Hence, provides an ideal condition to study the necessity for incrementing stages of repair using cell types that are able to enhance bone deposition and growth rate. The methodology used was assessed and approved by the Ethics Committee for Animal Experimention (CEEA) at the Federal University of Viçosa (UFV), under the protocol number 46/2007.

\section{METHODS}

Experimentation animals: Thirty two C57BL/6 isogenic male mice, weighing $30.0 \mathrm{~g}$ and aging six months were used. Eight young mice donated bone marrow for in vitro studies, and 24 adult mice were used for in vivo experimentation.
Animals were individually housed in $0.15 \mathrm{~m}^{2}$ cages in a controlled 12 hour light - 12 hour dark cycle, temperature, air humidity room and fed conventional rodent chow and water ad libitum.

Culture of mesenchymal stem cells: cells of primary culture were collected from the bone marrow of eight transgenic C57BL/6 mice for the reporter gene $g f p$ (green protein fluorescence), at three weeks of age, transferred to a growth plate with complete DMEM medium for cell culture (DMEM, SIMGA Chemycal Co., St. Louis, MO, USA ) and kept in oven incubator at 37 o $\mathrm{C}$ in $5 \%$ $\mathrm{CO}_{2}$ and $95 \%$ humidity.

Expansion of primary culture: the culture medium was fully withdrawn and flasks were washed with $3.0 \mathrm{~mL}$ of phosphate buffered saline solution (PBS 1x, pH 7.2). Next, cells attached to the bottom of the flask were trypsinized with trypsin solution $0.25 \%$ (Trypsin-EDTA $1 \mathrm{x}$, SIMGA Chemycal Co., St. Louis, MO, USA) and incubated at $37^{\circ} \mathrm{C}$ in $5 \% \mathrm{CO}_{2}$ and $95 \%$ humidity for 5 minutes. Later, cells were ressuspended in $5.0 \mathrm{~mL}$ of complete medium. Suspension with MSC was transferred to centrifuge tubes and centrifuged at $22^{\circ} \mathrm{C}$ and $1500 \mathrm{rpm}$ for 10 minutes. The supernatant was fully discarded and pellet was ressuspended in centrifuge tubes with $1.0 \mathrm{~mL}$ of PBS $1 \mathrm{x}$. An aliquot of $10.0 \mu \mathrm{L}$ of this new solution was diluted in $10.0 \mu \mathrm{L}$ of Trypan Blue Dye and homogenized in a sterile glass bottle. This solution was used for the cell counting in a Neubauer chamber. When a minimum cell concentration of $1.0 \times 107 \mathrm{cell} / \mathrm{s} / \mathrm{mL}$ was obtained, the tubes were once more centrifuged at $1500 \mathrm{rpm}$ for 10 minutes, stored in thermal boxes and transported to the surgical center and immediate transplanted into the isogenic C57BL/6 mice. At the time of implantation, the supernatant was discarded and only the pellet was used.

FACS analysis: cells from the fourth passage were harvested with trypsin, centrifuged and resuspended at $1.0 \times 10^{7}$ cells/well in phosphate-buffered saline (PBS). Cells aliquots were individually 
incubated with primary antibodies (anti-CD45 clone 69 mouse, anti-CD90 clone Ox-7 mouse, anti-CD73 clone 5 F/B9 mouse e anti-CD54 clone 1A29 mouse) [BD Bioscience, San Jose, CA, USA) for $30 \mathrm{~min}$ at $4^{\circ} \mathrm{C}$. After, the cells were washed in PBS and incubated with a fluorophore-conjugated secondary antibody (Alexa 488). The samples were analyzed using a FACScan cytometer and data were analyzed using CELLQUEST software (Becton Dickinson).

In vivo experimentation: Twenty four animals were randomly separated into two equal experimental groups, control (CG) and MSC (MG). Prior to surgery, animals received prophylactic antibiotic therapy with enrofloxacin $(10.0 \mathrm{mg} / \mathrm{kg}$, IM), and morphine based analgesics $(5.0 \mathrm{mg} / \mathrm{kg}$, SC) every 8 hours for three days. Following, they received xylazine $(5.0 \mathrm{mg} / \mathrm{kg}$, IP) as pre-anesthetic medication, while induction and maintenance of anesthesia was provided using isoflurane. Mice were placed on ventral recumbency, following trichotomy and antisepsis of the dorsal region of the skull, and the surgical area was delimited with sterile cloth.

Skin, subcutaneous and muscle were incised, approximately $1.0 \mathrm{~cm}$ oflength, on the external sagittal crest of the skull, from the occipital protuberance to near the eyes, allowing exposition of the parietal bone. A defect in the parietal region was created using a trephine drill with $6.0 \mathrm{~mm}$ of external diameter. The defect area was about $28.3 \mathrm{~mm}^{2}$ and penetrated the diploe completly exposing the meninges, which were kept intact at the bottom of the defect.

Animals in the MG had the defect filled with a pellet containing $1.0 \times 10^{7} \mathrm{cells} / \mathrm{mL}$ and the $\mathrm{CG}$ received no treatment. A resorbable demineralized cortical membrane of $0.7 \times 0.7 \mathrm{~cm}$ in extension was placed on the defect and just beneath the skin in both groups. Following, the skin was approximated with non-absorbable monofilament thread, in simple-separated points. Animals were observed twice a day throughout the experimental period and assessed concerning body weight, behavior, andwater and food consumption.
Periods of assessment: three animals of each group were identified, weighed and submitted to euthanasia with sodium thiopental overdose on days 10, 30, 60 and 90 after surgery. Subsequently, each mouse was contained on a surgical table for bone biopsies, involving the defect region and the lateral region of the receptor bone. The fragment was identified, measured, photographed and preserved in buffered formaldehyde for histological processing and polymerase chain reaction.

Macroscopic assessment: it consisted in the measurement of the defect area and establishment of the percentage of bone repair (initial area - measured area in each period/initial area) in millimeters (mm), through analysis of digital photos. Digital images were analyzed by specific program (IMAGELAB PRO PLUS ${ }^{\circledR}$, Media Cybernetics, Bethesda, MD, USA). The location and aspect of the defect and the presence of bone growth were also recorded.

Microscopic assessment: the defect area and edges of the receptor bone (longitudinal slices) were collected and submitted for histological processing. These were included in paraffin and sliced in microtomeand later stained with hematoxylin and eosin (HE). Samples were assessed concerning the presence and characteristics of the filling tissue by descriptive histological analysis.

DNA extraction: the genomic DNA of $g f p^{+}$ MSC maintained in culture was extracted from fresh bone tissue of $g f p^{-}$animals (negative control) and a paraffin embedded samples with bone tissue of the defect region and cell transplant, as per protocol of kit (QIAamp DNA Mini Kit (250), QIAGEN, Uniscience, São Paulo, SP, Brazil).

Polymerase Chain Reaction (PCR): PCR was performed to amplify a fragment of 225 base pairs (bp) of the $g f p$ gene using the primers: GFP-5C 5' ACT TCA AGA TCC CGC ACA ACA T 3' (direct) and GFP-3C 5' TTA CTT GTA CAG CTC GTC CAT CG 3' (reverse), and verify the presence of the $g f p$ gene in the tissue samples. The reaction was 
perfomed using a final volume of $25.0 \mu \mathrm{L}$ with the following reagents: $7.0 \mu \mathrm{L}$ of DNA of the sample; $2.5 \mu \mathrm{L}$ of primer $G F P-5 \mathrm{C}$ to $0.02 \mathrm{mM} ; 2.5 \mu \mathrm{L}$ of primer GFP-3C to $0.02 \mathrm{mM} ; 2.5 \mu \mathrm{L}$ of each dNTP to $2.0 \mathrm{mM}$ (dATP, dTTP, dGTP, dCTP); $2.5 \mu \mathrm{L}$ of buffer of Taq DNA polymerase 1x and 1U of Taq DNA polymerase (Taq DNA polymerase, Invitrogen Co, Carlsbad, CA - USA). Initially, PCR comprehended a denaturing phase at $94^{\circ} \mathrm{C}$ for 5 minutes, followed by 40 cycles of three steps: denaturing at $94^{\circ} \mathrm{C}$ for 35 seconds, annealing at $58^{\circ} \mathrm{C}$ for 45 seconds and extension at $72^{\circ}$ for 1 minute. A final extension step was performed at $72^{\circ} \mathrm{C}$ for 7 minutes. The PCR products were analyzed by $1.5 \%$ agarose gel electrophoresis, and stained with ethidium bromide solution for visualization in transluminator.

Statistical methods: results obtained by macroscopic measurements were submitted to Kolmogorov-Smirnov tests to verify the normality distribution of the variable percentage of bone repair. The mean percentage of bone repair in each evaluation period was established, and the analysis of independent samples was performed using Student's t-test. For such, a rejection level of the null hypothesis of $5 \%(\mathrm{p} \leq 0.05)$ was used.

\section{RESULTS}

Signs of infection in the surgical site, weight loss, or apathy were not observed during the daily inspections in the post-operatory period.

Twenty four hours after plating, the culture in complete DMEM presented adherent cells with a fibroblastoid morphology. Non-adherent cells were removed from culture during medium changes. After 3 days of culture, $80 \%$ of confluence was observed and the first passage was done. Intervals from 3 to 5 days were required to complete each passage, and these were performed until the fourth passage, which occurred at about 12 days (Figure 1A and 1B).

Phenotypic characterization of the MSC indicated that there were no CD45 expressions in $83.09 \%$ of the cells. There were expressions of CD54 (93.83\%), CD73 (70.44\%) and CD90 $(98.82 \%)$ (Figure 2).

Macroscopic assessment, regardless of the experimental group, demonstrated no bone growth beyond the receptor margins or underneath the meninges. Furthermore, complete closing of the defect as well as no adherence among structures such as brain, meninges or repair tissue was found

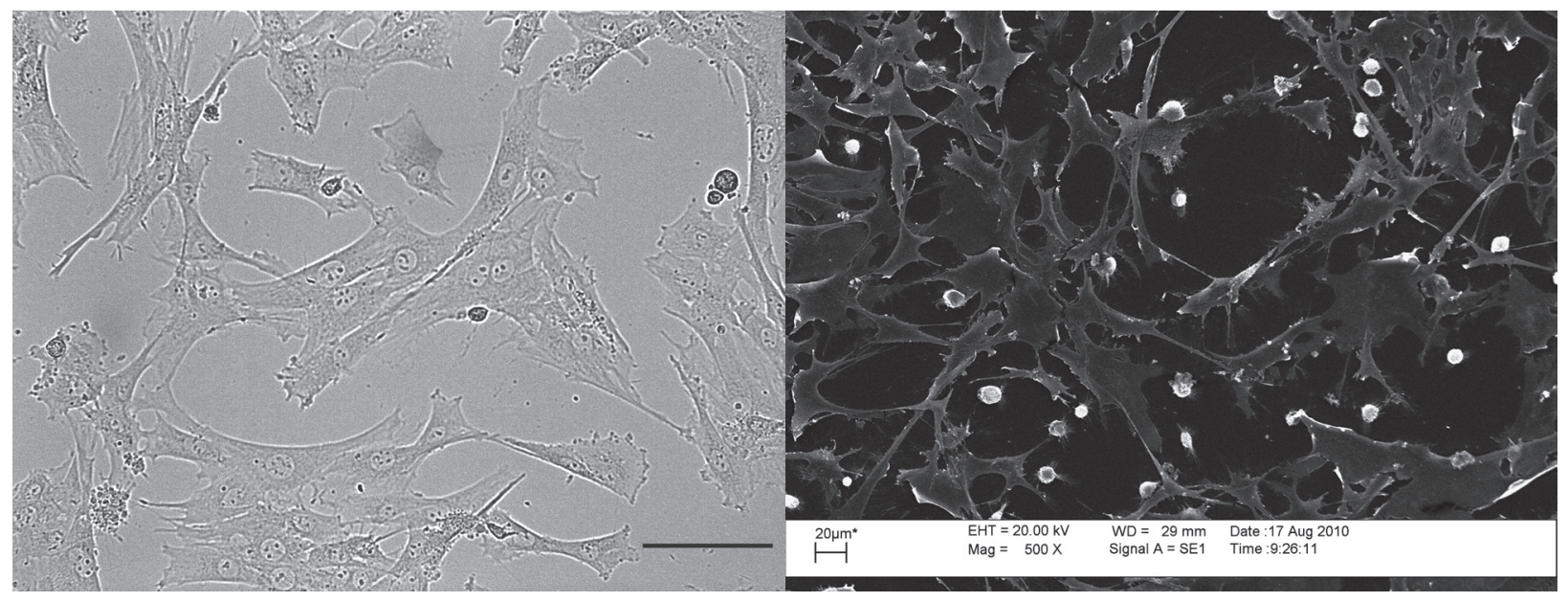

Figure 1 - Culture of mesenchymal stem cell in forth passage, with higher cell confluence and fibroblastoid-like cells adhered to the substrateand the culture flask. A) Photomicrograph captured of inverted optical microscope (escale $=50 \mu \mathrm{m})$. B) Photomicrograph captured of scanning electron microscope. 

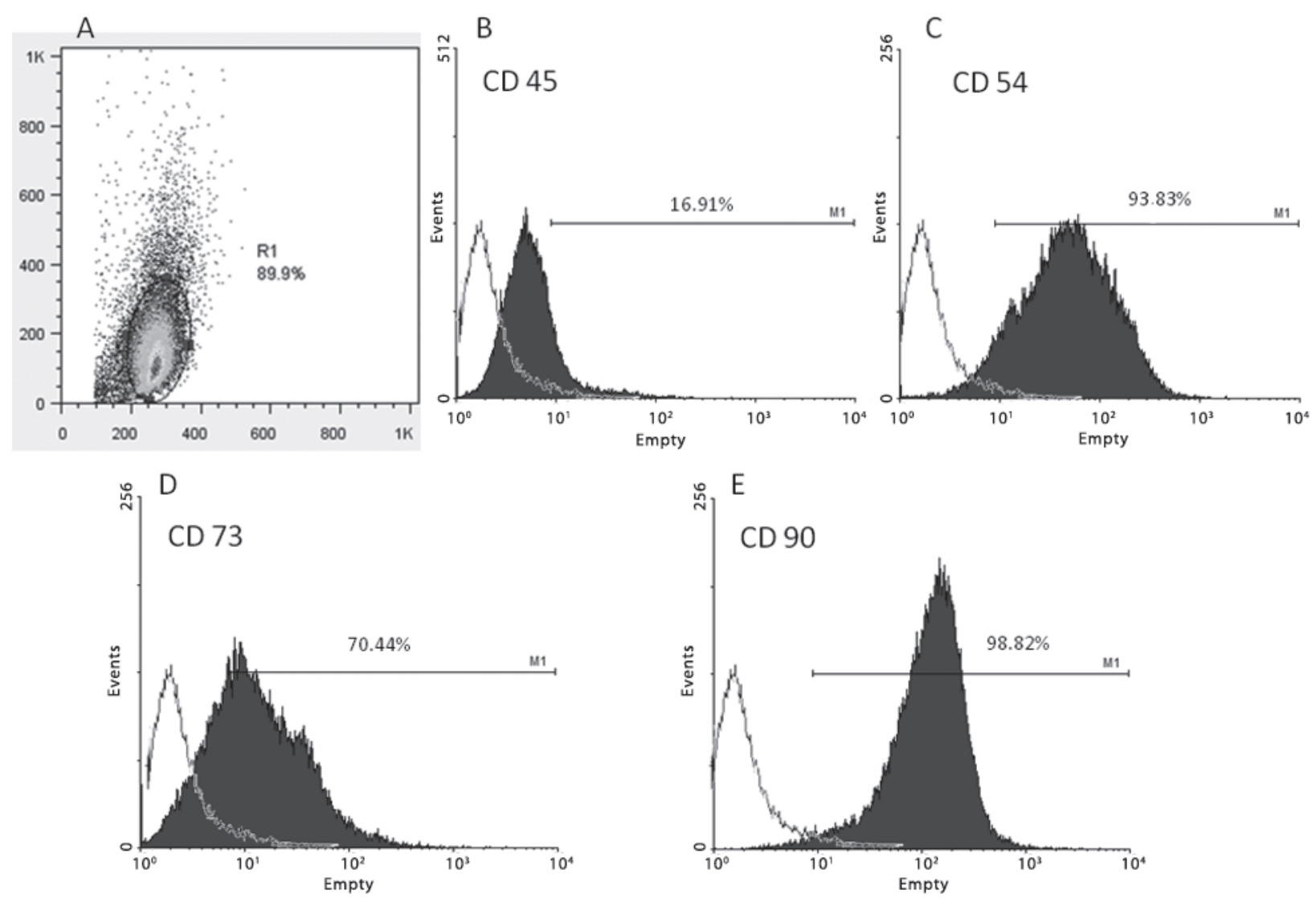

Figure 2 - Evaluation of the frequency of CD45, CD54, CD73 and CD90 by flow cytometry in mesenchymal stem cells derived from rats. The expression phenotype of CD54, CD73 and CD90 in $93.83 \%, 70.44 \%$ and $98.82 \%$ respectively, and no expression of CD45 in $83.09 \%$ of the cells evaluated.

throughout the evaluations. New bone filling the defect had smaller thickness compared to the surrounding receptor bone while the edges lost its circular, becoming irregular at the largest filling points for both, $\mathrm{CG}$ and $\mathrm{MG}$ throughout the assessment periods. The demineralized membrane placed on the defects was still present in two animals from the CG at 10 days of evaluation, but not in the MG. This membrane was not observed at other timepoints.

By variable analysis of the bone repair percentage difference $(p=0)$ between the two experimental groups in all assessment periods was verified, and MG animals had the best repair values. The values of this percentage in the MG, at 10 days, were only seen in CG after the period of 30 days. Still in MG, the percentage of repair occurred from the initial lesion day to the first 10 days was the highest one found (56\%), and decreased throughout days (day 11 to $30.6 \%$; day 31 to $60.3 \%$; day 61 to 90. 5\%). In CG, the highest percentage was found between days 11 and $30(30 \%)$ and the value seen at 90 days was similar to that at 30 days in the group treated by mesenchymal stem cells (Figure 3 ).

In the $10^{\circ}$ day, exams performed on light microscopy showed, cell multiplication with discrete bone formation at the defect edges and towards the center for the control group. Infiltration of basophilic cells replacing a region previously occupied by blood clot was observed. Most of the cells that were on the repair process were mainly originated from soft tissues (periosteum and muscle) present in the edges of the defect.

At 30 days, a greater bone formation was noticed compared to previous periods, characterized 


\begin{tabular}{ccccc}
\hline Treatment & $\begin{array}{c}\text { Period } \\
\text { (days) }\end{array}$ & $\begin{array}{c}\text { Means } \\
\text { of areas } \\
(\mathbf{m m})\end{array}$ & $\begin{array}{c}\text { Percentage of } \\
\text { bone repair } \\
\left(\mathbf{m m}^{\mathbf{2}}\right)\end{array}$ & $\begin{array}{c}\text { Estimated } \\
\boldsymbol{p} \text { value }\end{array}$ \\
\hline $\mathrm{CG}$ & 10 & 22.133 & 21.880 & \\
$\mathrm{MG}$ & 10 & 12.480 & 55.951 & $p=0.0000$ \\
$\mathrm{CG}$ & 30 & 13.863 & 51.069 & \\
$\mathrm{MG}$ & 30 & 10.844 & 61.725 & $p=0.0000$ \\
$\mathrm{CG}$ & 60 & 11.843 & 58.199 & \\
$\mathrm{MG}$ & 60 & 10.054 & 64.514 & $p=0.0000$ \\
$\mathrm{CG}$ & 90 & 10.495 & 62.957 & \\
$\mathrm{MG}$ & 90 & 8.458 & 70.147 & $p=0.0000$ \\
\hline
\end{tabular}

Figure 3 - Mean percentage of bone repair displayed by period of observation, for animals of groups control (CG) and MSC-treated (MG) and estimated $p$ values comparing data of $\%$ of bone filling, per period, of treatment MG versus treatment $\mathrm{CG}$.

by new tissue forming islets surrounded by granulation tissue which grew towards the interior of the defect. At this timepoint, the blood vessels permeating the granulation tissue were found in larger number to that observed at 10 days. At 60 and 90 days, the bone growth was progressive in relation to the observation time, with presence of bone marrow with mononuclear cells interspersing the bone diploe. The presence of big round cells with eosinophilic cytoplasm and basophilic nucleus suggestive of megakaryocytes was seen.

In group MSC (MG), there was a greater angiogenesis and quantity of new tissue deposited in the defect margins than those seen in CG. The quantity of new vessels was superior at 10 days when compared to the other periods in the same group. In some specimens, cell infiltrate constituted of basophilic cells replacing the region previously occupied by the blood clot was seen. At 10 days, intense cell movement from soft tissues present in the defect periphery and presence of undifferentiated cellular types, with cuboid morphology and round

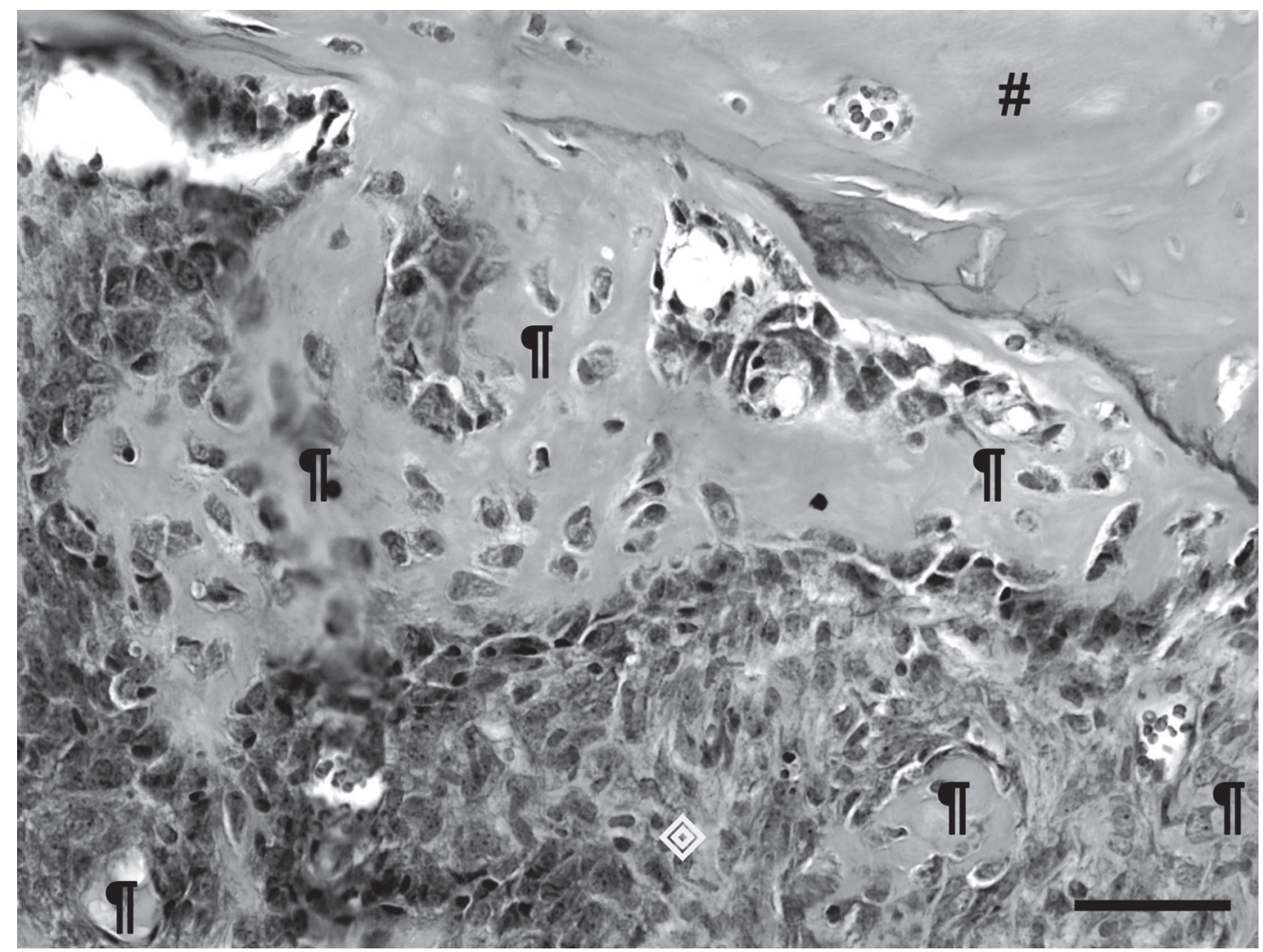

Figure 4 - Photomicrograph evidencing the microscopic aspect of the process of bone defect repair at 10 days in one animal from group MSC. Undifferentiated cellular types in the interior of the defect $(\diamond)$, new bone formation disposed in islands ( $($ ), and receptor bone (\#). (HE) [escale $=100 \mu \mathrm{m}]$. 
nucleo, occupying the defect interior and in contact with the receptor margins. In the central region, bone islands were evident, with small levels of tissue organization and deposition of cuboid cellular types, differentiated in bone cells, in the growth margins (Figure 4).

At 30 days, a higher bone tissue growth was seen, originating in the periphery and progressing towards the defect center, with small level of organization and showing presence of fibroblastoid undifferentiated cells organizing among new formations. At 60 days, a higher quantity of bone tissue and of higher organization than that as far observed was evidenced. Also, fibroblastoid undifferentiated cells and young cuboid cells near the recently formed bone were present. Hystological aspects seen at 90 days were similar to those reported in previous periods, with greater bone formation and greater organization of the osteoid tissue. Quantity and maturation of formed bone progressed concurrently to the time of observation.

In MG, greater quantity of osteoblasts and osteoid tissue was evidenced, organizing when compared to $\mathrm{CG}$ and regardless of the analysis time, cuboid osteoblasts in intense deposition activity of bone matrix were seen, lining up in the margins of the new tissue formation. With progression of the assessment period, discrete foci with signs of bone remodeling and/or presence of osteoclasts were seen.

The sample from tissue treated with MSC had the DNA fragment of reporter gene ( $g f p$ ) amplified by PCR and confirmed by agarose gel electrophoresis (Figure 5).

\section{DISCUSSION}

Specific characteristics of mesenchymal stem cells (MSC), including their proliferative potential and ability to differentiate into various cell and tissue types, such as bone, fat and cartilaginous, make them an attractive tool for regenerative medicine (Deans and Moseley 2000, Muraki et al. 2006, Breyner et al. 2010).

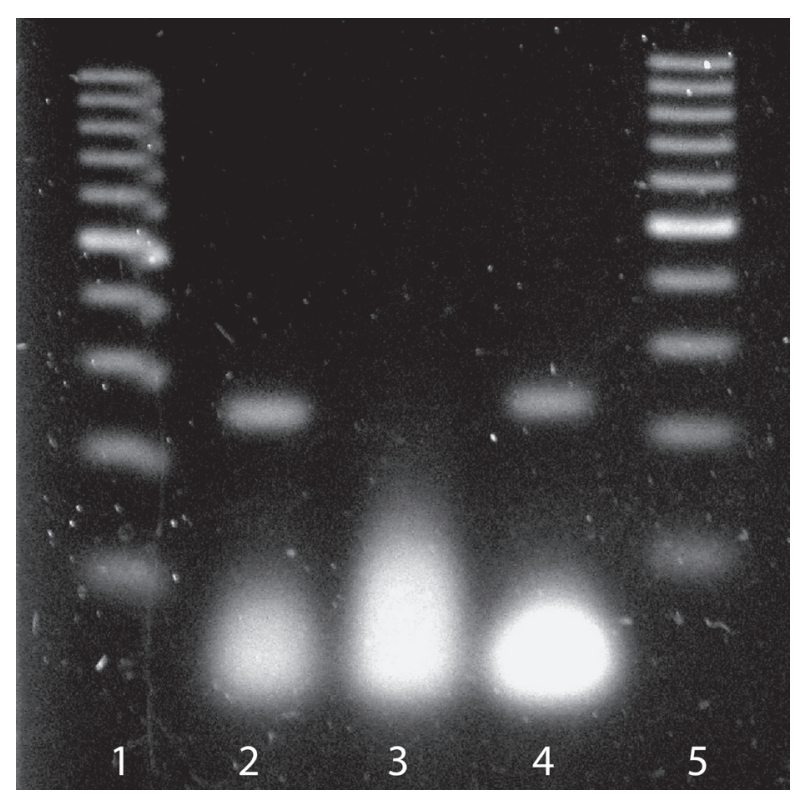

Figure 5 - Photography of agarose gel displaying banding of the samples submitted to PCR. Channels 1 and 5 have standard marker of 100 base pairs. Channel 2 with PCR product of cells in culture (positive control). Channel 3 with PCR product of the bone tissue sample of animal $g f p^{-}$(negative control). Channel 4 with PCR product of the paraffinized bone tissue sample of one animal treated with MSC/gfp ${ }^{+}$.

The expression of surface molecules CD54, CD73 and CD90, associated with low expression of CD45 (16.91\%) observed in this study, characterizes these cells phenotypically analyzed as MSC. High levels of CD90 and CD54 found - both above 90\% - are the most reliable to allow this conclusion, as the hematopoietic cells and fibroblasts that may be present in the culture don't express these markers (Nardi and Meirelles 2006).

The healing processes are complexes and need interactions between the damaged site and repair cells, we suggest that MSC incremented the bone formation process by releasing various types of growth factors in the medium, able to activate different cellular types, as elucidated by other authors (Deans and Moseley 2000, Bobis et al. 2006).

In the initial assessment period, in $\mathrm{MG}$, a marked presence of cell infiltrate constituted by basophilic cells was seen, and based on previous statements 
(Deans and Moseley 2000, Bobis et al. 2006) it is possible to infer that these cells might have had chemotactic influence of soluble factors released in the medium, accounting for this presence in greater quantity. For Honma et al. (2008) the inflammatory process triggered by the surgical procedure might have begin and keep the differentiation of MSC in osteoblasts. Similarly, Lacey et al. (2009) showed the potential of pro-inflammatory cytokines, such as IL-1 and IL-6 and tumor necrosis factor (TNF- $\alpha$ ), positively influencing the osteogenic potential for promoting the OPG and RANKL production, two cytokines that act in the deposition and bone resorption processes. The inflammatory phase was fundamental in the repair process, because it resulted in the activation and differentiation of osteoprogenitor cells and activation of young bone cells.

The treatment of defects using MSC showed a larger bone formation in relation to control, but, even at the end of the assessment period at 90 days, in both groups the defects were not completely filled. This characteristic allow for recognition that a critical defect in the calvaria of mouse, with $6.0 \mathrm{~mm}$ diameter, was created. In addition, it proves literature data that state that in this animal species the defects whose diameters exceed $2.7 \mathrm{~mm}$ are considered critical (Seo et al. 2008). Consequently, much as treatment with stem cells has increased the repair process, it wasn't enough to contribute to total repair. Also, it is known that bone defects repair in skull still represents a great challenge for orthopedics due to the small repair ability of this region (Del Carlo et al. 1994, Monteiro et al. 2007).

Seo et al. (2008) used human stem cells from primary teeth for repair of critical defects in calvaria of immune compromised mice and had total repair of bone defect. However, differently from what is presented in this work, the authors created defects of $2.7 \mathrm{~mm}$ and assessed the rats after of 6 months. Therefore, equivalent to the limit of critical defect, less than half the size of the defect performed in this research and assessed twice as long.
The statistical study proved that treatment with MSC increased the bone repair process and resulted in growth of a greater quantity of new bone, mostly in the first 10 days after treatment, the earlier stage. It was noticed that the highest rate of bone repair displayed in the control group at 90 days was similar to the rate of the treated group at 30 days.

The resorbable demineralized membrane had the purpose of avoiding dispersion of the material deposited in the interior of the lesion since a mouse doesn't have muscles and subcutaneous tissue in this region of the calvaria in sufficient quantity to be sutured and prevent the leakage of cells that were used in the treatment. In the assessment performed at 30 days in both groups, it was no longer present, consistently with data from the preliminary pilot study, performed by the authors, which verified that it doesn't influence the process of bone repair and is fully absorbed in a period of 15 days.

According to Martin (1997) and Tsirogianni et al. (2006), in a process of tissue repair, the first stage involves formation and organization of the blood clot during the first 24 hours. After this period, the clot begins to be replaced and, around the ninth to eleventh day, replacement by granulation tissue is complete. In MG, the cell infiltrate constituted of basophilic cells replacing the region previously occupied by the blood clot was seen only in some specimens, unlike $\mathrm{CG}$, where this replacement was seen in all samples and on several observation points. Possibly, in MG, the presence of greater quantity of cells available in the repair site might have anticipated this clot replacement.

In the first assessment period, at 10 days, the presence in MG of great quantity of cells with morphology cuboid or fibroblastoid was seen in the interior of the defect, being part of the formation of new bone tissue. This event wasn't seen in CG, possibly because the observed cells were MSC used in the treatment and/or undifferentiated cells chemo-attracted by the soluble factors released in the medium. At 30, 60 and 90 days, fibroblastoid cells in between the new 
bone growth were also detected, but morphology was different from the cells observed at 10 days. Possibly, at 10 days, the present cells were those transplanted, and at 30,60 and 90 days the undifferentiated cells were those attracted to the repair site.

The intense cellularity from soft tissues present in the periphery of the defect and moving in a centripetal way, especially in $\mathrm{MG}$, show the contribution of bone cells present in the periosteum for the repair process. Shimizu et al. (2001) had already shown that, among cells that constitute the repair, in the periosteum there are progenitors with potential for differentiating into osteoblasts, which are activated by physical or chemical stimulation, as in the cases of fractures, inflammations and tumor arising, and that contribute for repair processes. With the same purpose, Zhang et al. (2005) stated that, in addition to the role of proliferation and differentiation in cartilage and bone cells, mesenchymal progenitor cells, present in the periosteum, also release osteoinduction factors able to recruit and activate other osteocompromised cells of the host.

In MG, a greater angiogenesis and bone formation was seen, in relation to CG. The greater bone formation reflects the presence of greater quantity of osteoblasts, which might have originated by different mechanisms of differentiation of the mesenchymal precursor cells (Herzog et al. 2003, Meirelles et al. 2006) and/or were attracted to the defect site by paracrine effect (Moore and Quesenberry 2003). Once present in the margins of the lesion, these osteogenic cells secrete bone protein matrix, including type I collagen and proteoglycans and stimulate the mineralization and formation of osteoid tissue (Bobis et al. 2006, Shen et al. 2005).

Concerning the bone formation, the cellular types present in both groups were the same. Cuboid osteoblasts were seen, in rows in the edges of the new bone formation, and discrete presence of osteoclasts near the new forming blood vessels. The difference between groups was the quantity of bone deposition cells, superior in MG.
When assessing the contributions of the repair therapies with MSC, it is essential to consider the characteristic of the site where cells will be deposited. According to Fuchs et al. (2004) the therapeutic success depends on niche, i.e., interaction of stem cells with other cells, with extracellular matrix and with the medium growth factors, which will maintain these cells quiescent and/or under process of differentiation. This way, the breeding of surgical and asseptical wounds, and the application of cells in an acute point of the lesion process (therapeutic window) favored the maintenance, differentiation and release of the other soluble factors by MSC, contributing for the upper formation of bone tissue in MG.

The presence of band in the agarose gel detected in the treated animal, similar to that verified in the positive control, proved the presence of the reporter gene in animals treated with MSC $g f p^{+}$and allows us to infer that stem cells used in the treatment are still present in the bone repair process.

It was verified by macroscopic, statistical, microscopic and molecular assessments that the use of mesenchymal stem cells (MSC) derived from the bone marrow of C57BL/ $6 g f p+$ young mice applied in critical bone defects produced in calvaria of C57BL/6 adult mice positively contributes for the process of bone repair.

\section{ACKNOWLEDGMENTS}

We thank Dr. Nance B. Nardi, Laboraty of Immunogenetics, Universidade Federal do Rio Grande do Sul (UFRGS), and Dr. Joaquin H. Patarroyo Salcedo, Laboratory of Biology and Control Hematozoa Vectors and the Universidade Federal de Viçosa (UFV). This study was supported by Fundação de Amparo à Pesquisa do Estado de Minas Gerais (FAPEMIG), Coordenação de Aperfeiçoamento de Pessoal de Nível Superior (CAPES) and Conselho Nacional de Desenvolvimento Científico e Tecnológico (CNPq). 


\section{RESUMO}

As células-tronco mesenquimais (MSC) estão presentes em nichos especializados nas regiões perivasculares dos tecidos adultos e são capazes de se diferenciar em diversos tipos celulares, dentre eles, os comprometidos com processos de reparação óssea. MSC oriundas da medula óssea de oito camundongos jovens C57BL/6 $g f p^{+}$ foram expandidas em culturas e utilizadas na reparação de defeitos críticos produzidos em calvária de 24 camundongos isogênicos C57BL/6 adultos. Os animais foram submetidos a um defeito craniano de $6,0 \mathrm{~mm}$ de diâmetro e separados em dois grupos experimentais iguais. $\mathrm{O}$ grupo controle não recebeu tratamento e no grupo tratado foi administrado, no interior do defeito, pellet de MSC contendo 1,0 x $10^{7}$ células/mL. O grupo tratado com MSC exibiu aumento da angiogênese e maior quantidade de novo osso depositado nas bordas do defeito, comparando-se ao grupo controle. Nas condições experimentais apresentadas nesse estudo, constatou-se que o transplante de células-tronco mesenquimais (MSC) derivadas da medula óssea de camundongos C57BL/6 $g f p^{+}$, aplicadas em defeitos ósseos críticos, produzidos em calvária de camundongos contribui positivamente para o processo de reparação óssea. As MSC apresentam habilidades de influenciar o correto funcionamento dos osteoblastos, aumentar a quantidade de células mobilizadas nos processos de reparação, aumentar a liberação de fatores de crescimento e aumentar a deposição de matriz óssea.

Palavras-chave: terapia óssea, células-tronco mesenquimais, enxerto autólogo, camundongo, calvária.

\section{REFERENCES}

Bielby R, Jones E AND MCgOnagle D. 2007. The role of mesenchymal stem cells in maintenance and repair of bone. Injury 38: S26-S32.

BOBIS S, JAROCHA D AND MAJKA M. 2006. Mesenchymal stem cells: characteristics and clinical applications. Folia Histochem Cytobiol 44: 215-230.

Breyner NM, Hell RC, Carvalho LR, Machado CB, Peixoto Filho IN, VAlério P, Pereira MM AND Goes AM. 2010. Effect of a three-dimensional chitosan porous scaffold on the differentiation of mesenchymal stem cells into chondrocytes. Cells Tissues Organs 191: 119-128.
CAPLAN AI. 1991. Mesenchymal stem cells. J Orthop Res 9: 641-650.

CAPLAN AI. 2009. Why are MSCs therapeutic? New data: new insight. J Pathol 217: 318-324.

DeAns RJ AND Moseley AB. 2000. Mesenchymal stem cells: Biology and potencial clinical uses. Exp Hematol 28: 875-884.

Del Carlo RJ, Iamaguti P, Branco MDL and Susko I. 1994. Cranioplastia por interposição de auto-enxerto costal. III. Aspectos da enxertia óssea. Arq Bras Med Vet Zootec 46: 244-252.

Fuchs E, Tumbar T AND GuAsCH G. 2004. Socializing with the neighbors: stem cells and their niche. Cell 116: 769-778.

Herzog EL, Chai L AND KRAUSE DS. 2003. Plasticity of marrow-derived stem cells. Blood 102: 3483-3493.

HONMA T, ITAGaKi T, NAKAMURA M, KAMAKURA S, TAKAHASHI I, ECHIGO S AND SASANO Y. 2008. Bone formation in rat calvaria ceases within a limited period regardless of completion of defect repair. Oral Dis 14: 457-464.

HorwITZ EM ET AL. 1999. Transplantability and therapeutic effects of bone marrow-derived mesenchymal cells in children with osteogenesis imperfecta. Nat Med 5: 309-313.

LaCEY DC, Simmons PJ, GRaves SE And Hamilton JA. 2009. Proinflammatory cytokines inhibit osteogenic differentiation from stem cells: implications for bone repair during inflammation. Osteoarthr Cartil 17: 735-742.

MARTIN P. 1997. Wound healing - aiming for perfect skin regeneration. Science 276: 75-81.

MeIrelles LS, CAPlan AI AND NARDI NB. 2008. In search of the in vivo identity of mesenchymal stem cells. Stem Cells 26: 2287-2299.

Meirelles LS, Chagastelles PC AND NARdi NB. 2006. Mesenchymal stem cells reside in virtually all post-natal organs and tissues. J Cell Sci 119: 2204-2213.

Monteiro BS, Del CARlo RJ, Pinheiro LCP, Viloria MIV, SILVA PSA, SoUZA LPO AND BALBINOT PZ. 2007. Proteínas morfogenéticas ósseas (BMPs) associadas a osso esponjoso autógeno na reparação de falhas experimentais na calota craniana de coelhos. Arq Bras Med Vet Zootec 59: 745-751.

MoOre BE AND QUESENBERry PJ. 2003. The adult hemopoietic stem cell plasticity debate: idols vs new paradiMGs. Leukemia 17: 1205-1210.

Muraki K, Hirose M, Kotobuki N, Kato Y, Machida H, TAKAKURA Y AND OHGUSHI H. 2006. Assessment of viability and osteogenic ability of human mesenchymal stem cells after being stored in suspension for clinical transplantation. Tissue Eng 12: 1711-1719.

NARDI NB AND MEIRELLES LS. 2006. Mesenchymal stem cells: Isolation, in vitro expansion and characterization. Handb Exp Pharmacol 174: 249-282.

PitTenger MF, MACKAY AM, BeCK SC, JAISWAL RK, Douglas R, Mosca JD, MoOrman MA, SimONETTI DW, CRAIG S AND MARSHAK DR. 1999. Multilineage potential of adult human mesenchymal stem cells. Science 284: 143-147.

Seo BM, Sonoyama W, Yamaza T, Coppe C, Kikuiri T, AKIYAMA K, LEE JS AND SHI S. 2008. SHED repair critical-size calvarial defects in mice. Oral Dis 14: 428-434. 
Shen F, Ruddy MJ, Plamondon P AND GAFFEn SL. 2005. Cytokines link osteoblasts and inflammation: microarray analysis of interleukin-17 and TNF- $\alpha$ induced genes in bone cells. J Leukoc Biol 77: 388-399.

Shimizu T, Sasano Y, Nakajo S, Kagayama M and SHIMAUCHI H. 2001. Osteoblastic differentiation of periosteum-derived cells is promoted by physical contact with the bone matrix in vivo. Anat Record 264: 72-81.
TSIROGIANNI AK, MOUTSOPOULOS NM AND MOUTSOPOULOS HM. 2006. Wound healing: immunological aspects. Injury 375: S5-S12.

Zhang X, Xie C, Lin ASP, Ito H, Awad H, Lieberman JR, RUBERY PT, SCHWARZ EM, O'KEEFE RJ AND GULDBERG RE. 2005. Periosteal progenitor cell fate in seMGental cortical bone graft transplantations: implications for functional tissue engineering. J Bone Miner Res 20: 2124-2137. 